\title{
The intrapleural volume threshold for ultrasound detection of pneumothoraxes
}

\author{
NP Oveland ${ }^{1,2^{*}}$, E Soreide $^{2,3}$, F Johannessen ${ }^{4}$, K Wemmelund $^{5}$, R Aagaard $^{5}$, HM Lossius ${ }^{1}$, E Sloth $^{5,6}$ \\ From London Trauma Conference 2012 \\ London, UK. 4-7 December 2012
}

\section{Objectives}

Small pneumothoraxes (PTXs) may not impart an immediate threat to trauma patients after chest injuries. However, if these patients require positive pressure ventilation even a small amount of pleural air may be relevant. Point-of-care lung ultrasonography (US) is a reliable tool in the diagnosis of PTX, but the performance characteristics regarding detection of miniscule PTXs needs to be defined. We aimed at finding the volume threshold of intrapleural air where PTXs confidently can be diagnosed.

\section{Methods}

Air was insufflated into a unilateral pleural catheter in seven incremental steps $(10,25,50,100,200,350$ and $500 \mathrm{~mL}$ ) in twenty intubated porcine models, followed by a diagnostic evaluation with US and a supine anteroposterior chest radiograph (CXR). The sonographers continued the US scanning until the PTXs could be ruled in, based on identification of the US sign "lung point". The corresponding threshold volume was noted. A senior radiologist interpreted the CXRs images.

\section{Results}

The mean threshold volume to detect miniscule PTXs using US was $17.8 \mathrm{~mL} \pm 12.8 \mathrm{~mL}$, range $10 \mathrm{~mL}$ to $50 \mathrm{~mL}$. Sixty-five \% of the PTXs were diagnosed at $10 \mathrm{~mL}, 25 \%$ at $25 \mathrm{~mL}$ and the last $10 \%$ at $50 \mathrm{~mL}$ of intrapleural air. The radiologist correctly diagnosed 266 lungs (71.1\%), had 93 false negative and 15 false positive interpretations. The sensitivity was $31.1 \%$ and the specificity $93.8 \%$; the $95 \%$ confidence intervals were $(22.6,38.7)$ and $(89.7$, 96.4), respectively.

'Department of Research and Development, Norwegian Air Ambulance Foundation, Droebak, Norway

Full list of author information is available at the end of the article

\section{Conclusion}

Miniscule PTXs could be diagnosed with a high level of accuracy using lung US; thus recommended performed by clinicians treating chest trauma patients when PTX is among the differential diagnoses.

\section{Abbreviations \\ PTX: pneumothorax; US: Ultrasound; CXR: Chest radiography; CT: Computed tomography}

\section{Author details}

'Department of Research and Development, Norwegian Air Ambulance Foundation, Droebak, Norway. ${ }^{2}$ Department of Anaesthesiology and Intensive Care, Stavanger University Hospital, Stavanger, Norway.

${ }^{3}$ Department of Surgical Sciences, University of Bergen, Bergen, Norway. ${ }^{4}$ Department of Radiology, Stavanger University Hospital, Stavanger, Norway. ${ }^{5}$ Faculty of Health Sciences, Institute of Clinical Medicine, Aarhus University, Aarhus, Denmark. ${ }^{6}$ Department of Anaesthesiology and Intensive Care, Aarhus University Hospital, Aarhus, Denmark.

Published: 28 May 2013

doi:10.1186/1757-7241-21-S1-S4

Cite this article as: Oveland et al:: The intrapleural volume threshold for ultrasound detection of pneumothoraxes. Scandinavian Journal of

Trauma, Resuscitation and Emergency Medicine 2013 21(Suppl 1):S4.

Submit your next manuscript to BioMed Central and take full advantage of:

- Convenient online submission

- Thorough peer review

- No space constraints or color figure charges

- Immediate publication on acceptance

- Inclusion in PubMed, CAS, Scopus and Google Scholar

- Research which is freely available for redistribution 